\title{
Students' Use of Translation as a Learning Strategy in EFL Classroom
}

\author{
Zeinab Karimian (Corresponding author) \\ Shahreza Branch, Islamic A zad University, Iran \\ Mohammad Reza Talebinejad \\ Shahreza Branch, Islamic A zad University, Iran
}

\begin{abstract}
Translation has long played a controversial role in English teaching and learning. It has been largely ignored as a valid activity for language practice and improvement. On account of this matter, although, most language educators are completely against the use of translation in language classrooms, nowadays, this perspective is changing and more and more professionals have believed the facilitating role of the first language in ELT. On the basis of this matter, this issue has been discussed in applications of language pedagogical methodologies. The main purpose of the present study was to investigate Iranian English learners' use of translation as a learning strategy to learn English. It is also to find out the strategies involving translation the students use in the process of learning. In order to do all this, the study employed quantitative and supplemental qualitative methods. For the quantitative part, 170 Iranian EFL learners were asked to answer the Inventory for Translation as a Learning Strategy (ITLS) questionnaire. For the qualitative survey, 120 students were selected to respond the learners' interview guide. Then, the data analysis and statistical calculations revealed that language learners used a wide variety of learning strategies concerning translation to comprehend and remember as well as produce English whether or not they are discouraged to do so by their teachers.
\end{abstract}

Index Terms - foreign language learning, learning English, learning strategies, translation

\section{INTRODUCTION}

After the application of translation in Grammar Translation Method (GTM), it has been banned from the language classroom for quite a while in methods, mostly including the early versions of the communicative approaches to ELT, in L2 language pedagogy. In addition, 'the only time that L1 is mentioned is when advice is given on how to minimize its use' (Cook, 2001). Although the role of mother tongue in foreign language teaching has been neglected by most of language teachers, many of language learners use their mother tongue in learning a new language (Naiman, Frohlich, Stern, and Todesco, 1978; Politzer 1983; Chamot, O'Malley, Küpper, and Impink-Hernandez, 1987). Therefore, during 1970s and 1980s, the use of learners' first language was rejected in communicative methods (Kavaliauskienë \& Kaminskienë, 2007). Because of such a reason, the association of translation with the language learning became less and less for centuries. Moreover, L1 using was gradually omitted in foreign and second language learning classes. However, recently the attitude toward the use of translation in language learning has been shifted positively. Further, teachers and in a broad way students have considered translation a supportive strategy and got benefits from it. Corder (1981) also emphasizes that students' mother tongue is a useful resource for the learners to compensate their deficiencies in second language learning. Regard ing the issue, Weschler (1997) concludes, combining the good points of both "grammar-translation" and "communicative" approaches can lead to a strong method which can largely be meaning-based rather than the form-based.

It does not matter how students are qualified in reading or listening, most of language learners keep the mental translating a language into another. Based upon this issues EFL educators gave attention to the importance of L1 in language learning process (Kavaliauskienë \& Kaminskienë, 2007). According to Harmer (2001), the use of both students' mother tongue and code-switching between two languages are naturally helping things in learning a new language. Students' use of native language may be differentiated based upon their attitudes and skills. He also express that "No one is in any doubt that students will use their L1 in clas s, whatever teachers say or do". As a result, rejecting translation in language classes seems to create a stressful situation to great many students, if considered tactfully, there are many ways and benefits of using translation in both EFL teaching and EFL learning. On the basis of this matter, this issue has been discussed in applications of language pedagogical methodologies. So the present study aimed to analy ze the strategies through them translation could be considered as a helping factor for the learners to arrive at their learning objectives in EFLclasses. 
With the growing importance of learner-centered language teaching, what helps the learner in his or her own way has been an asset. On the basis of this fact, researchers have attempted to lighten the load of language learning, and have investigated what is helpful for learners to arrive at their objective in the most economical way. A mong them the use of translation and also its place has been a debatable topic.

In the past, by the use of GTM, studying a language for a long time could not guarantee the language learners' fluency. On account of such a reason, although, most language educators are completely against the use of translation in language classrooms, nowadays, this perspective is changing and more and more professionals have believed the facilitating role of the students' native tongue in language classrooms (Liao, 2006; Cook, 2010). On the basis of learners' beliefs toward EFL learning, it has been considered; learners' attitudes would probably influence their style in using diverse methods while learning in some researches. For instance, Horwitz' (1988) survey indicated that language learners' beliefs would limit their use of strategy while learning a foreign language.

In Iran, the mother tongue, Farsi, is the formal language of education. All students do their primary education in their mother tongue. If these students could be given an early exposure to the English language it would make a big difference to them. Therefore, ignoring the use of learners' first language in language classes could naturally lead to the students' de-motivation. The purpose of the present study is to deal with translation as a fruitful material in language classes and get rid of its name from what considered badly in GTM. Therefor challenging problem is to consider that whether translation use in EFL learning and EFL teaching is as facilitating or debilitating matter.

\section{RESEARCH QUESTIONS}

Where, the role of learners' mother tongue in learning process is not precisely stated and mostly its nature is misunderstood, the present study intended to investigate and determine the function of translation from students' perceptions in Iranian EFL classes.

Regarding above-mentioned matter, it was an attempt to find answers to the following questions:

1. To what extent do Iranian English learners make use of their mother tongue as a learning strategy?

2. What strategies involving translation do Iranian learners' use in the process of English learning?

\section{METHODOLOGY}

\section{A. Participants}

One hundred and seventy both male and female students taking English courses in language schools with the age range of 15-30 participated in this study. At the first part of the study, all of the survey participants took part in quantitative survey. Then, for the qualitative measure, these English learners took part in Quick Placement Test, a standard and valid test. This was done to choose participants for the second part of the study. To fulfill the study forty students of each English proficiency levels (beginner, intermed iate and advanced) were chosen to participate, and the remains were eliminated from the study. These survey language learners were in about 15 different groups at language institutes.

\section{B. Instruments}

Data collection of the present study was through the following instruments.

\section{Quick Placement Test}

To differentiate participants' English proficiency, and divide them into three levels of English language skills for the study, the researcher administered Quick Placement Test. It is a reliable and valid test, a 60-item multiple choice test, evaluating the language learners' level of L2 proficiency. It includes five meaning-based items, 25 ite ms in the form of cloze passages, 20 items to assess learners' knowledge of structure, and finally 10 items evaluate to the students' vocabulary knowledge.

\section{Learning Strategy Questionnaire}

To identify the learning strategies regarding translation, learning strategy questionnaire was administered. The questionnaire was firstly designed by Liao (2006).

The questionnaire is of a Likert-scale design. There were 5 scales for each item from "completely disagree", which represents the lowest rank of participants' using translation as a learning strategy to "completely agree", which indicates the most use of this strategy. The questionnaire was firstly translated into the survey participants' native language to assist them better understand intentions of items.

\section{Inter view Guide for students}

The gathering interview data were to add extra information to complete the quantitative part. The interview was used to receive more to the point data concerning English learners' use of translation strategies. An interview is mostly "an interest in understanding the experience of other people and the meaning they make of that experience" (Seidman, 1998). Moreover, the main goal of an interview is to "find out what is in or on someone else's mind" (Patton, 1990). Through the help of an interview the researcher probes the students' minds and also their viewpoints regarding English learning in order to improve a better understanding toward the function of learners' native tongue in language learning process. 
Following interview guide approach, the interview questions in this study, used for the students, focused on (1) learners' reflections and evaluations of their use of mother tongue as a strategy in language learning process. Interview guide for the students was designed basically based upon what Liao (2006) worked on. The questions were somehow modified regarding the new students' culture and fulfilled in Persian language, the students' native language; to assist better understanding of all language learners (especially beginners who are mostly of low Eng lish proficiency).

\section{RESULTS}

\section{A. Descriptive Statistics of the Learning Strategies}

Addressing the first research question, the language learners were asked to rate the Learning Strategy items on the five point Likert scale from completely disagree to completely agree. First of all, the percentage of each scale (on ITLS items) was measured and then displayed in Table5.1.

TABLE 5.1.

THE PERCENTAGE OFLEARNERS' PERFORMANCE ON ITLS ITEMS

\begin{tabular}{|l|l|l|l|}
\hline & Number & Percent & Total percent of disagree \\
\hline completely disagree & 447 & 9.72 & 26.47 \\
\hline Disagree & 770 & 16.75 & \\
\hline no idea & 865 & 18.82 & Total percent of agree \\
\hline Agree & 1363 & 29.65 & \multirow{2}{*}{54.69} \\
\hline completely agree & 1151 & 25.04 & \\
\hline Total & 4596 & 100.0 & \\
\hline
\end{tabular}

The result show that the highest level of percentage was given to agree, and completely agree was rated as the second one in both tables. The participants' responses (about 54 percent) were to indicate most of the participants accepted the mother tongue as a helping strategy in their new language (English) learning.

Moreover, to complete the result, the researcher also computed means of learning strategy items to help find how the language learners expressed their use of translation as a strategy in language learning process. The scores of items indicated that

Most of the items were of the highest means. The learners reported that they made use of their first language to benefit of mentally translation in reading English texts. They emphasized that translation is helpful mostly in outlin ing their ideas and also their writings, understanding the meanings of utterances in a piece of listening, and learning English idioms and expression. Further, most of the students verified, bilingual dictionaries could help them learn English both in and out of the class. Additionally, the gathered data showed that a lot of Iranian English learners discussed the differences and similarities between Persian and English through their own mother tongue.

\section{B. Students' Use of Learning Strategies by Means of Translation}

In this study, Learners used translation as an affective strategy. In their eyes, with the help of translation, learners could be encouraged more to learn English language and understand it better. The following remarks described this is sue.

The use of translation can increase our sense of security to learn what we do not know, and also help us to feel comfortable beside our teachers in the EFL classes.

In my English language classes, when the teacher explained all materials in English, it caused a threatening environment. As a result, my classmates and I could not ask our questions, and just looking each other.

I feel satisfied and secure when my teacher speaks Persian occasionally. It helps me conceive I know what I need about the lesson. If not so, I doubt what I have perceived is correct or not. Challenging this mat ter, it takes me so long and seems more difficult to learn what I really need.

In the study, almost all of the learners agreed using their mother tongue as compensation in Iran ian EFL classes. The following statements highlight the mentioned strategy.

While writing a composition, after gathering some in formation in Persian I translate it to English. During the writ ing, when I cannot find the English equivalence of the words, I have to look up the words in Persian - English dictionary.

Since most students do not familiarize with English language in EFL classes, when the teacher speaks just English they do not understand what he/she means. In these situations the learners get used to loathing the English language. As a result what is a help is nothing except learners' mother tongue.

While reading a te xt, I underline the difficult words. After that, I refer to English _ Persian dictionary.

Retrieval strategy (using the keyword mnemonic in order to retrieve the meaning of a given vocabulary word) and me mory strategy are two other strategies noted in the following words.

Learning and memorizing some new English words requires a lot of practice and effort. Besides, just for a few days I can remember them. In order to solve this problem I try to connect the word to some event in Persian. This event can be 
matched to the pronunciation of the word, and requires me a little effort to memorize. So, as I hear or see the word the way it pronounced helps me remind its meaning after a few seconds.

When I memorize the Persian meaning of English new words or new idioms, if I forget the words, their Persian meanings are good help to remind those words.

Some other responses indicate that language learners mostly use their first language as a social strategy to learn and produce English. The following statements confirm the idea.

Owing to lack of knowledge of words, sometimes in order to comprehend some part of a text, I have to ask my classmates to translate it to Persian, but I try to do when teacher is not around.

Oftentimes my classmates and I have to translate what the teacher is talking about together in the class and out of the class to support our understanding of the lesson.

In free discussion moments, sometimes it is necessary to elaborate on the issue in Persian. Then ide as concerning the topic would be discussed in English to the whole class.

\section{DISCUSSION}

The result of the study and also from most previous studies was the fact that translation plays a positive role in EFL classes. Moreover, students use it as a helping strategy in order to learn and improve their new language learning. These findings were somehow consistent with Chamot et al. (1987) finding that the translation strategy was considered a base for language learners' comprehension and production of the target language. Further, Liao (2006) reported that students mostly used their mother tongue to expand their English knowledge of vocabulary, structures, expressions, and to improve 3 language skills of reading, writing, and speaking. Moreover it can help the learners to check their comprehension of different tasks, especially reading and listening ones. The results contradict what Kobayashi and Rinnert (1992) came up with in their study. They stated that most of university students in Japan, about $77 \%$, pre ferred directly use of English in their composition writing. They also mentioned that these students intended to think directly in the second language. In this regard, based upon the study done in Taiwan, Huang and Tzeng (2000) noted that Taiwanese high proficient English learners mostly use the target language in their language learning process. In other word, only $11 \%$ of the muse their first language as a helping strategy in reading skill improvement.

Supplemental qualitative survey with one hundred and twenty language learners revealed that using L1 in language learning process not only decreases learners' an xious but also enhances their English learning encouragement.

Another reason of using translation in their EFL classrooms related to the providing of an affective situation positively.

The result is consistent with Husain's (1996) finding in which it was clarified that students' mother tongue in language learning process could intensify the learners' confidence and also give them the positive feeling of relaxation. It was said that the learners' stress could be decreased by making use of translation. Further, Wenden's (1986) found that the adult English learners felt afraid or nervous when they spoke just English. Moreover, based upon what the students mentioned, translation sometimes compensate for their lack of knowledge. This finding supports Kern's (1994) result that foreign language students make a large amount of translation from second language into first language mentally while reading a text. Additionally, similar to findings of the present study, Danchev (1983) expressed that translation can facilitate not only a swift solving of structurally complication in the second language but also a quick and effective comprehension.

Fro m the students' ideas, other strategies highlighting the positive role of translation in ELT were guessed. Students get benefit from retrieval strategy and memory strategy in vocabulary acquisition. The result is consistent with Prince (1996) finding. In comparing using translation with context learning, he found that in expanding the knowledge of L2 lexicon, the role of first language is more significant than the function of vocabulary learning contextually.

From the students' perspectives and also from the previous studies, social strategy which is the interaction among students in language pedagogy shows that in language pedagogy, making use of learners' mother tongue plays an integral role in both language perception and its production. In the eye of Donato and Mccormick (1994), strategies used in language pedagogy are mainly emerged from socially participation of language learners in the language classes. Consequently, it can be claimed that learners' use of translation refers to social strategy a process in direct contact with the activities fulfilled in language classes.

\section{CONCLUSIONS}

The finding of this study involved that translation is a supporting factor in language pedagogy in order to learn and improve learners' new language learning. In other words, students employed some different translation strategies to assist them improve their knowledge of English regarding different skills and solve language problems. For instance, I can say that some learners need the security of their mother tongue to lower their English learn ing an xiety moreover, in order to be motivated. Besides, students used translation to memorize and retrieve English, to make up for their deficiencies in English language, to self-assess and comprehend their target language tasks, and have an interaction with other people in learning English. 
In conclusion, with regard to translation use in language learning process some strategies were clarified among the survey language learners. These strategies are sometimes performed to remove the learners' class anxieties and worries and make the m feel more self-confident and relaxed. Furthermore, they are used to compensate the learners' English lack of knowledge, memorize and retrieve some complicated words and structures, and also fulfill the difficult activities and tasks socially both in and out of the class. According to results of the study, it is concluded that Iranian students' make use of translation as a strategy to help them learn English in language learning process. Regarding the correlation between learners' attitudes toward translation and their strategy use, the obtained highest results appeared that they are not only positively correlated but also greatly related to each other. To sum up, language learners mostly believed in using translation, and also used it as a helping strategy in language pedagogy. Besides, they endorsed translation not to train professionals, but to help learners develop their knowledge of English. In other words, it is a means to an end, not an end to be achieved.

\section{REFERENCES}

[1] Chamot, A., O’Malley, J. M., Küpper, L., \& Impink-Hernandez, M. V. (1987). A study of learning strategies in foreign language instruction: First year report. Rosslyn, VA: InterAmerican Research Associates.

[2] Cook, G. (2010). Translation in language teaching. Oxford: Oxford University Press.

[3] Cook, V. (2001). Using the first lan guage in the classroom. The Canadian Modern Language Review, 57 (3), $402-423$.

[4] Corder, S. (1981). Error Analy sis and Interlanguage. Oxford: Oxford University Press.

[5] Danchev, A. (1983). Translation in the system of foreign languages training. Paris: Round Table FIT-UNESCO.

[6] Donato, R., \& Mccormick, D. (1994). A sociocultural perspective on language learning strategies: The role of mediation. The Modern Language Journal, 78(4), 453-464.

[7] Harmer, J. (2001). The practice of English language teaching. Oxford: Lon gman.

[8] Horwitz, E.K. (1988). The Beliefs about Lan guage Learning of Beginning University Foreign Lan guage Students. The Modern Language Journal, 72, 283-94.

[9] Huang, S., \& Tzeng, C.S. (2000). Learning strategies used by high English proficiency learners in Taiwan, paper presented at the Ninth International Symposium on English teaching. Taipei, Taiwan, ROC.

[10] Husain, K. (1996). Translation in the history of language teaching. International Journal of Translation, 8(1-2), 111-120.

[11] Kavaliauskienë, G., \& Kaminskienë, L. (2007). The effect of individual differences on learners' translation beliefs in EFL learning. Kalbotyra, 57(3), 132-139.

[12] Kern, R. (1994). The role of mental translation in second language reading. Studies in Second Language Acquisition, 16, 44161.

[13] Kobayashi, H., \& Rinnert, C. (1992). Effects of first language on second language writing: Translation versus Direct Composition. Language Leaning, 42, 183-215.

[14] Liao, P. S. (2006). EFL learners' beliefs about strategy use of translation in English learning. RELC Journal, 37(2), 191-215.

[15] Naiman, N., Frohlich, M., Stern, H. H. \& Todesco, A. (1978). The good lan guage learner. Toronto: Ontario Institute for Studies in Education.

[16] Patton, M. Q. (1990). Qualitative evaluation and research methods. Newbury Park, CA: Sage.

[17] Politzer, R.L. (1983). An exploratory study of self-reported language learning behaviors and their relationship to achievement. Studies in Second Language Acquisition, 6, 54-68.

[18] Prince, P. (1996). Second language vocabulary learning: The role of context versus translation as a function of proficiency. The Modern Language Journal, 80, 478- 93.

[19] Seidman, I. (1998). Interviewing as qualitative research. NY: Teachers College Press.

[20] Wenden, A. (1986). What do second-language learners know about their language learning? A second look at retrospective accounts. Applied Linguistics, 7(2), 186-201.

[21] Weschler, R. (1997): Uses of L1 in the English classroom: Introducing the Functional-Translation Method. Retrieved on June, 2011 from: http://iteslj.org/Articles/Weschler-UsingL1.html.

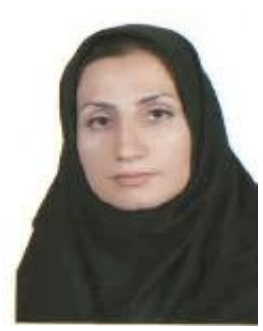

Zeinab Karimian was born in yasouj, Iran, on July 23, 1979. She received her B.A. in TEFL from Shiraz Azad University, Shiraz, Iran in 2007. She furthered her university studies on English education for an M.A. degree in TEFL and earned her M.A. degree from Shahreza Azad University, Isfahan, Iran in 2012.

As an EFL teacher, she has been teaching English to Iranian EFL learners in several lan guage schools and universities since 2007. She is currently teaching English courses at different universities and lan guage schools in yasouj, Iran. She has also presented some papers in national conferences in Iran. This paper is based on her Master's thesis. 


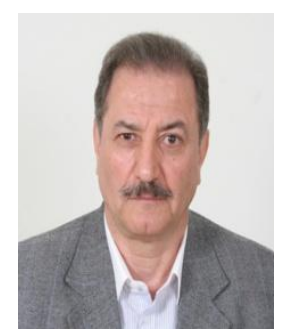

Mohammad Reza Talebinejad is an Associate Professor of Applied Linguistics at Islamic Azad University, Shahreza Branch. He is also an associate faculty member at Sheikhbahaee University, Iran.

Dr Talebinejad received his BA in English Language and Literature, University of Isfahan in 1975. He then got his MA in TEFL from the University of Texas at Austin, USA in 1977. For his doctoral degree, Dr Talebinejad was admitted to the University of Sheffield, UK, where he did his $\mathrm{PhD}$ in Applied Linguistics in 1994.

He has widely published in Iranian as well as International professional journals such as Metaphor and Symbol, English Teaching Forum, Language Testing, IJAl, Language and Translation, Journal of Social Sciences, The International Journal of Humanities, and other local and international journals. Dr Talebinejad has presented papers in International conferences such as AILA, 2000; Atiner, 2011; RAAM, 2002, 2001 in Paris and Tunis, EUROSLA, Switzerland, 2006; Multicultural Conference, 2007, China. In addition, Dr Talebinejad has authored/coauthored eight books in related fields and ESP. 